\title{
PRECURSOR SELECTION FOR PROPERTY OPTIMIZATION IN BIOMORPHIC SiC CERAMICS
}

F.M. Varela-Feria, M.J. López-Robledo, J. Martínez-Fernández, and A.R. de Arellano-López

Dept. de Física de la Materia Condensada, Universidad de Sevilla, Spain

M. Singh

QSS Group, Inc., NASA Glenn Research Center

Cleveland, OH 44135-3191

\begin{abstract}
Biomorphic $\mathrm{SiC}$ ceramics have been fabricated using different wood precursors. The evolution of volume, density and microstructure of the woods, carbon performs, and final $\mathrm{SiC}$ products are systematically studied in order to establish experimental guidelines that allow materials selection. The wood density is a critical characteristic, which results in a particular final $\mathrm{SiC}$ density, and the level of anisotropy in mechanical properties in directions parallel (axial) and perpendicular (radial) to the growth of the wood.
\end{abstract}

\section{INTRODUCTION}

Materials selection is crucial for engineering design [1]. This is especially important when ceramics are considered for technological applications. Processing of ceramics with a specific set of properties is normally expensive and time consuming [2]. Choosing the appropriate raw material is the first and probably one of the most critical steps in the production of ceramic materials. In the case of structural ceramics, under well-controlled fabrication procedures, monolithic oxides like mullite, and non-oxides like $\mathrm{SiC}$ and $\mathrm{Si}_{3} \mathrm{~N}_{4}$, have proven to be good candidates for high-temperature applications where strength and stiffness are important [3]. However, a number of these fabrication technologies are not cost-effective and difficult to scale-up.

Microstructural complexity is thought to be the determining factor in strong ceramics, as in biological materials like bones, shells, and wood. Several efforts have resulted in artificial microstructures that resemble that of natural materials (continuous-fiber reinforced ceramics [4], porous ceramics [5], fibrous ceramics monoliths [6], etc). However, natural materials also offer unique properties in terms of optimal mechanical response with low density, achieved by a porous and interconnected structure $[7,8]$.

\footnotetext{
This report is a preprint of an article submitted to

a journal for publication. Because of changes that may be made before formal publication, this

preprint is made available with the understanding

that it will not be cited or reproduced without the

permission of the author.
} 
A recently developed fabrication technique [9-19] allows the fabrication of $\mathrm{SiC}$ from natural wood precursors. The main advantages of the technique are, in summary, low cost and near net-shape fabrication. The diversity of wood microstructures offers a large variety of options in terms of material selections. The two main characteristics that can be selected are the wood density, which results in a particular final $\mathrm{SiC}$ density, and the level of anisotropy in mechanical properties [15-17] in directions parallel (axial) and perpendicular (radial) to the growth of the wood. The only necessary condition is that the wood present a connected porosity, with a minimum pore size of about $5 \mu \mathrm{m}$ to allow an efficient infiltration at $1550^{\circ} \mathrm{C}$.

The purpose of this work is to explore experimental laws that can help choose a type of wood as precursor for a final SiC product, with a given microstructure, density and level of anisotropy. Preliminary studies of physical properties suggest that not only mechanical properties are strongly anisotropic, but also electrical conductivity and gas permeability, which have great technological importance.

\section{EXPERIMENTAL}

The biomorphic $\mathrm{SiC}$ is fabricated by the melt infiltration method, for which general details have been described in the literature [9, 14-18]. In summary, the wood is dried and then pyrolyzed in an argon atmosphere at $1000^{\circ} \mathrm{C}$ with wellcontrolled heating and cooling ramps. Then, the liquid silicon infiltration is performed in vacuum at $1550^{\circ} \mathrm{C}$. Wood and carbon densities were measured geometrically and the biomorphic SiC density was measured by Archimedes method. The microstructure has been analyzed by scanning electron microscopy ${ }^{1}$.

\section{RESULTS AND DISCUSSION}

The process described previously was applied to wood precursors with a range of densities (Table 1). In this table, the maximum $\mathrm{SiC}$ percentage stands for the smaller of the $\mathrm{SiC}$ amounts calculated both as if full reaction of the carbon had taken place, and as if all the final product density were $\mathrm{SiC}$.

Typically in all kind of woods, approximately $74 \pm 5 \%$ of the starting weight of the natural precursor is lost during the pyrolysis, mainly in the form of water vapor and other volatiles (Fig. $1 \mathrm{a}, \mathrm{R}^{2}=0.945$ ). Volume is reduced at the same time by about $60 \pm 5 \%$ (Fig. $1 \mathrm{~b} \mathrm{R} \mathrm{R}^{2}=0.9696$ ). The relationship between carbon and wood density is then:

$$
\rho_{C} \approx 0.65 \rho_{\text {Wood }}
$$

The microstructure of the carbon preforms is critical to the infiltration process, and the biomorphic $\mathrm{SiC}$ properties, as the final $\mathrm{SiC}$ product resembles the microstructure of carbon preform. The analysis of their microstructures is then essential.

\footnotetext{
${ }^{1}$ Philips XL30, 30 kV, Servicio de Microscopía Electrónica, Universidad de Sevilla
} 
Table 1: Densities of precursors, carbon preforms, final products ( $\mathrm{SiC}+\mathrm{Si}$ ), and maximum content of $\mathrm{SiC}$ presented in this work.

\begin{tabular}{|l|c|c|c|c|}
\hline \multicolumn{1}{|c|}{ Wood type } & $\begin{array}{c}\text { Wood } \\
\text { density } \\
(\mathbf{g} / \mathbf{c m})\end{array}$ & $\begin{array}{c}\text { Carbon } \\
\text { density } \\
(\mathbf{g} / \mathbf{c m})\end{array}$ & $\begin{array}{c}\text { Final Product } \\
\text { density } \\
\left(\mathbf{g} / \mathbf{c m}^{\mathbf{3}}\right)\end{array}$ & $\begin{array}{c}\text { máximum } \\
\text { content of } \\
\text { SiC } \mathbf{( \% )}\end{array}$ \\
\hline Cork & 0.21 & 0.03 & No infiltration & -- \\
\hline Pine (Flanders) & 0.53 & 0.33 & $1.7 \pm 0.1$ & 34 \\
\hline Beech & 0.69 & 0.49 & $1.7 \pm 0.1$ & 51 \\
\hline $\begin{array}{l}\text { White } \\
\text { Eucalyptus }\end{array}$ & 0.84 & 0.67 & $2.03 \pm 0.05$ & 63 \\
\hline Spanish Oak & 0.88 & 0.78 & $2.1 \pm 0.2$ & 65 \\
\hline Bamboo & 1.04 & 0.78 & No infiltration & -- \\
\hline Red Eucalyptus & 1.13 & 0.91 & No infiltration & -- \\
\hline
\end{tabular}
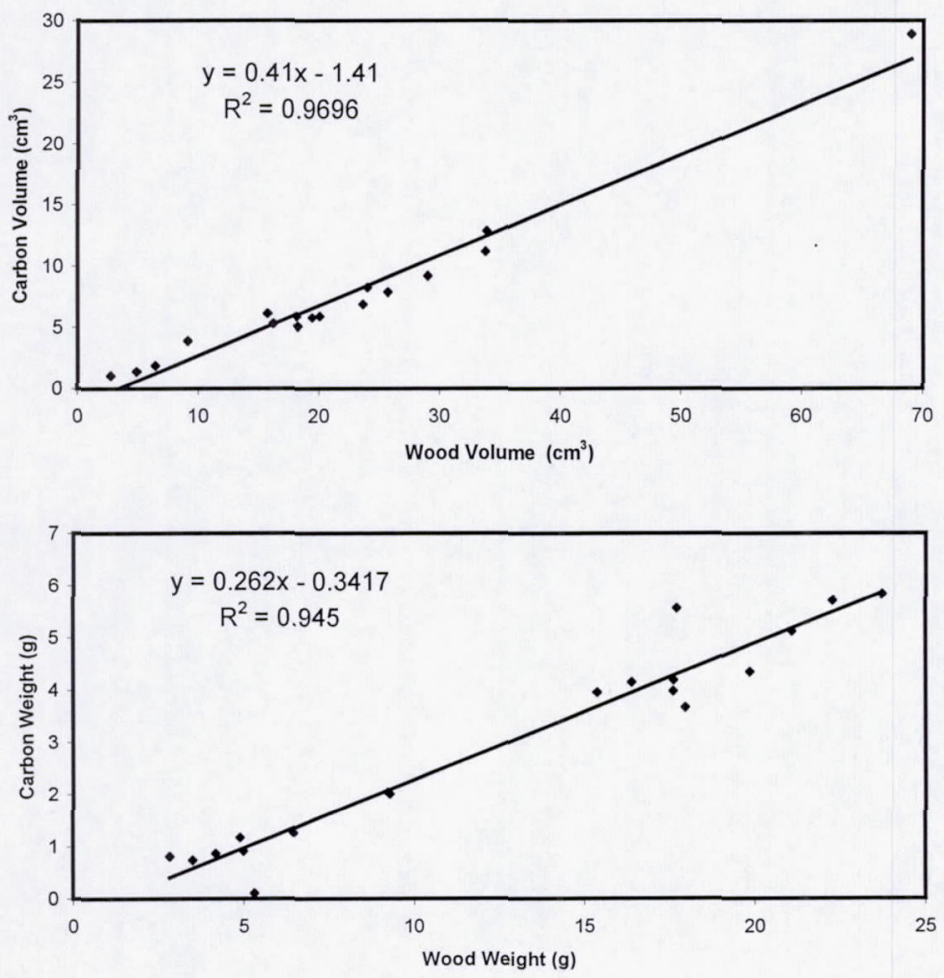

Fig. 1: Plot of the weight and volume change of wood (including all type of woods studied) after pyrolysis. 
The main features of the preform studies are:

- Carbon preforms from cork have equiaxial cells that are clearly not interconnected (Fig. 2a)

- Carbon preforms from bamboo contain a combination of long channels forming groups of two or four, which are responsible for the flexibility of the precursor, and closed cells (Fig. 2b).

- Carbon preforms from Flanders pine consist of long interconnected cells with rectangular section and typically $4-5$ neighbors (the microstructure is extensively discussed in references).

- Carbon preforms from beech have a bimodal size distribution of cells with the large cells taking most of the volume (Fig. 2c).

- Carbon preforms from white eucalyptus have the typical bimodal distribution of cell sizes typical of hard woods with a larger volume of small pores than in performs obtained from beech (the microstructure is extensively discussed in references). Small channels and large regions of radial cells (Fig. 2d and 2e).

- Carbon preforms from red eucalyptus have a microstructure similar to performs made from Spanish oak but with finer small channels (Fig. 2f). The average radius of the pores is $1.1 \mu \mathrm{m}$ versus $4.3 \mu \mathrm{m}$ in Spanish oak (Table 2).

It is clear that an increase in the density is associated with the transition to the bimodal distribution of pore sizes typical of hardwoods. Further increases in density causes a gradual decrease of the volume fraction of the larger pores. On the high-density end, small pores are the main constituents of preforms. The pore sizes and distributions are detailed in Table 2.

Table 2: Stereological parameter of the carbon performs.

\begin{tabular}{|c|c|c|c|c|c|c|}
\hline \multirow{2}{*}{$\begin{array}{c}\text { WOOD } \\
\text { TYPE }\end{array}$} & \multicolumn{3}{|c|}{ LARGE PORES } & \multicolumn{3}{c|}{ SMALL PORES } \\
\cline { 2 - 7 } & $\begin{array}{c}\text { Average } \\
\text { area }\left(\mu \mathbf{m}^{2}\right) \\
/ \text { radio }(\mu \mathrm{m})\end{array}$ & $\begin{array}{c}\text { SD area } \\
/ \text { radio }\end{array}$ & $\begin{array}{c}\% \\
\text { total } \\
\text { area }\end{array}$ & $\begin{array}{c}\text { Average } \\
\text { area }\left(\mu \mathbf{m}^{2}\right) \\
/ \text { radio }(\mu \mathrm{m})\end{array}$ & $\begin{array}{c}\text { SD } \\
\text { area }\end{array}$ & $\begin{array}{c}\% \\
\text { total } \\
\text { area }\end{array}$ \\
\hline Pine & $710 / 15.0$ & $\begin{array}{c}380 / \\
11.0\end{array}$ & 50 & & & \\
\hline Beech & $1188 / 19.4$ & $\begin{array}{c}794 / \\
16.0\end{array}$ & 43 & $22.5 / 2.7$ & $10 / 1.8$ & 5.0 \\
\hline White Eucalyptus & $1400 / 21.1$ & $\begin{array}{c}659 / \\
14.5\end{array}$ & 12.2 & $13.5 / 2.1$ & $8.6 / 1.6$ & 30.1 \\
\hline Spanish Oak & $1437 / 21.4$ & $\begin{array}{c}930 / \\
17.2\end{array}$ & 7.2 & $59 / 4.3$ & $32 / 3.2$ & 16 \\
\hline Eucalyptus Red & $16735 / 73.0$ & $\begin{array}{c}11121 / \\
59.5\end{array}$ & 8.2 & $3.9 / 1.1$ & $3.8 / 1.0$ & 15.7 \\
\hline
\end{tabular}

As a consequence of their total or partial content of closed cells, cork and bamboo carbon preforms do not infiltrate completely, and are not suitable to be 
used as precursors for this fabrication procedure. On the other end of the density range, the carbon preforms from red eucalyptus has pore sizes that are too small. The pores close during silicon carbide formation from the volume increase of the reaction and the infiltration only occurs on the surface. It seems then that there is a critical pore size between 1 to $4 \mu \mathrm{m}$ for the infiltration.

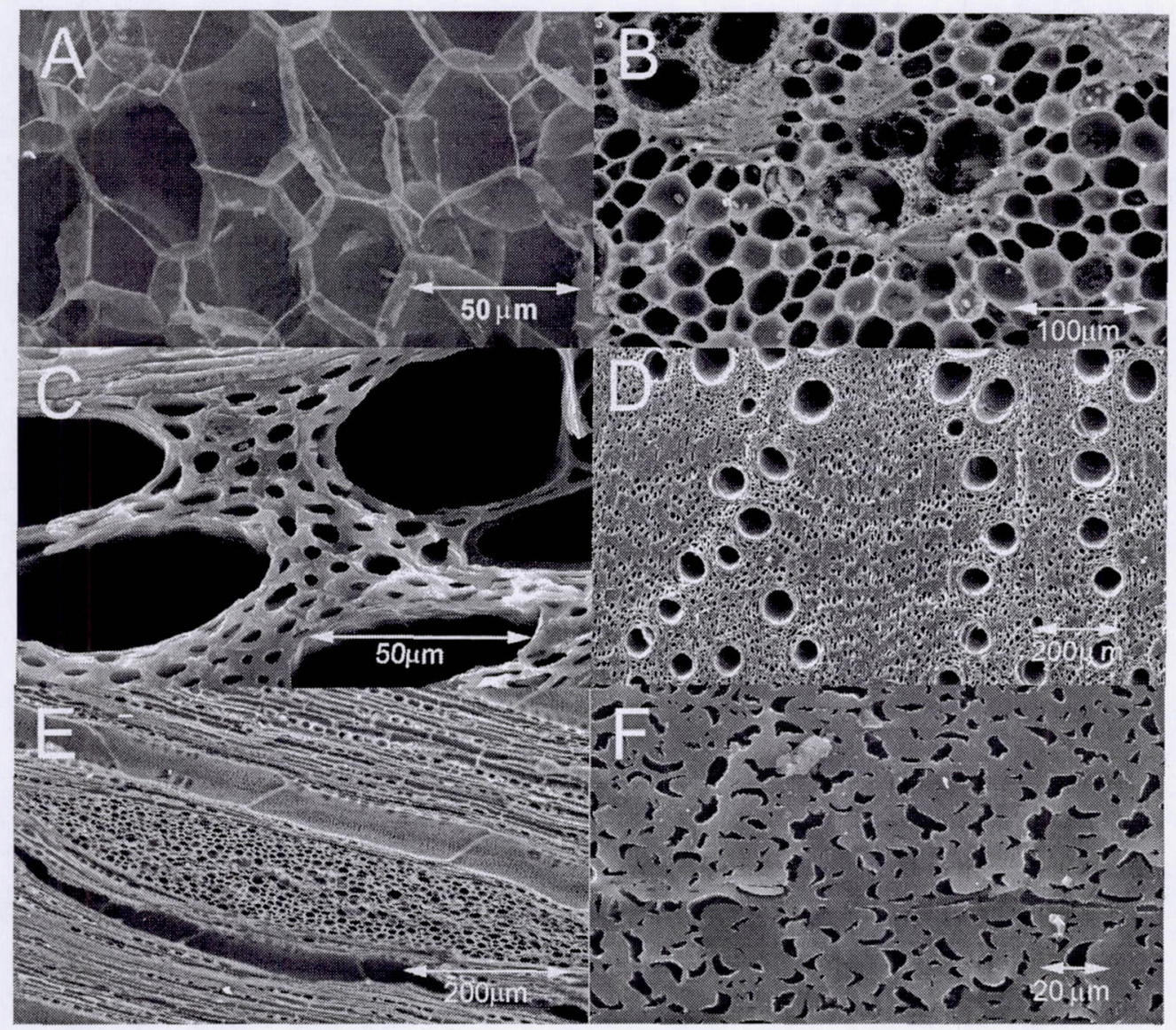

Fig 2: SEM micrographs of carbon performs from: A) cork, B) bamboo, C) beech, D) Spanish oak (axial), E) Spanish oak (longitudinal), and F) red eucalyptus.

In all the other preforms the silicon was able to infiltrate and react throughout the carbon preform. The biomorphic $\mathrm{SiC}$ resulting from this process did not show any measurable change in volume with respect to the carbon preform. This is an important issue because this indicates that net shape ceramics can be fabricated from pre-shaped carbon preforms.

The density of the maximum possible $\mathrm{SiC}$ density versus the wood density has a good linear fit $\left(\rho_{\mathrm{SiC}, \max }=2.35 \rho_{\mathrm{wood}}, \mathrm{R}^{2}=0.9603\right.$ ) that will be very helpful for choosing an adequate wood precursor. 
Additionally, previous work indicates that there is a power dependence of the strength with the density, the density exponents being around 1.5-2 for the axial direction and 3.5-4 in the radial direction. This fact, together with the previous relation between wood and $\mathrm{SiC}$ density, makes it possible choosing the wood precursor for a specific application requiring a certain strength. The strength anisotropy, however, is not predictable from a simple analysis of the wood density, and a microstructural study is necessary. Low strength anisotropy studied in previous works $[15,18]$ can be correlated with microstrucutral features like large amount of radial cells (spanish oak) and cell interlocking (eucalyptus).

\section{CONCLUSIONS}

The fabrication of $\mathrm{SiC}$ by the infiltration of carbonaceous preforms, fabricated by pyrolysis of wood, produces biomorphic SiC-based ceramics with a microstructure that resembles the wood precursor. The use of several precursors covering a wide range of densities and microstructure led to the following conclusions:

- There is a very good correlation between wood density and biomorphic SiC density, what makes easy predicting the right precursor for achieving a specific density and strength.

- The lack of interconnections between cells and small channel size, the critical size being between 1 to 4 microns, are factors impeding silicon infiltration.

- The cell interlocking in the axial direction and the amount of radial cells are factors controlling strength anisotropy.

\section{ACKNOWLEDGEMENTS}

This work is supported by the Spanish Government, Ministerio de Ciencia y Tecnología, grant 1FD97-2335, and by the Andalusian Government under a

"Ayuda para la Transferencia de Tecnología".

\section{REFERENCES}

1. M.F. Ashby, "Materials Selection in Mechanical Design", Butterworth Heinemann, Oxford, 1999

2. J.S. Reed, "Principles of Ceramics Processing", Wiley Interscience, 1995.

3. J.B. Wachtman, "Mechanical Properties of Ceramics", John Wiley and Sons, New York, 1996

4. R. Naslain, "Materials Design and Processing of High-Temperature Matrix Composites: State of The Art and Future Trends", Adv. Composite Mater., 1999, 8, [1], 3-16.

5. L.J. Gibson, and M.F. Ashby, "Cellular Solids: Structure and Properties", 1988, Pergamon Press, New York.

6. D. Kovar, B.H. King, R.W. Trice, J.W. Halloran, "Fibrous Monolithic Ceramics", J. Am. Ceram. Soc., 1997, 80, [10] 2471-87. 
7. M. Alper, "The Biological Membrane”, Mat. Res. Bull., 1992, 17, 53.

8. J.E. Mark and P.D. Calvert, "Biomimetic, Hybrid and In-situ Composites", Mater. Sci. and Engg., 1994, C1, 159-170.

9. M. Singh, "Environment Conscious Ceramics (Ecoceramics)", Ceram. Sci. Eng. Proc., 2000, 21 [4] 39-44.

10. P. Greil, T. Lifka, and A. Kaindl, "Biomorphic Silicon Carbide Ceramics from Wood : I and II", J. Europ. Ceram. Soc., 1998, 18, 1961.

11. D.-W. Shin, S.S. Park, Y.-H. Choa and K. Niihara, "Silicon/silicon carbide composites Fabricated by infiltration of a silicon melt into charcoal", J. Am. Ceram. Soc., 82, 3251 (1999).

12. H. Sieber, A. Kaindl, H. Friedrich, and P. Greil, "Crystallization of SiC on Biological Carbon Precursors", Ceram. Trans., 2000, 110, (Bioceramics: Materials and Applications III), Ed.: George. L., Rusin, R. P., Fischman, G. S., and Janas, V., The American Ceramic Society, 81-92.

13. G. Qiao, R. Ma, N. Cai, C. Zhang, and Z. Jin, "Mechanical properties and microstructure of $\mathrm{Si} / \mathrm{SiC}$ materials derived from native wood", Mater. Sci. Engg., A 323 (2002) 301-305.

14. M. Singh, "Environment conscious ceramics (Ecoceramics)", NASA/TM2001-210605, NASA Glenn Research Center, Cleveland, OH.

15. F.M. Varela-Feria, S. López Pombero, A.R. de Arellano López, J. MartínezFernández, "Maderas Cerámicas: Fabricación y Propiedades del Carburo de Silicio Biomórfico", accepted for publication in Bol. Soc. Esp. Ceram. y Vidrio, 2002.

16. J. Martínez-Fernández, F.M. Varela-Feria, M. Singh, "Microstructure and Thermomechanical Characterizacion of Bimorphic Silicon Carbide-Based Ceramics", Scripta Mater., 2000, 43, 813-18.

17. F.M. Varela-Feria, S. López Pombero, J. Martínez-Fernández, A.R. de Arellano López, and M. Singh, "Creep Resistant Biomorphic Silicon-Carbide Based Ceramics", Ceram. Eng. Sci. Proc., 2001, 22, [3], 135-145

18. F.M. Varela-Feria, J. Martínez-Fernández, A.R. de Arellano López, and M. Singh, "Low Density Biomorphic Silicon Carbide: Microstructure and Mechanical Properties", accepted for publication in J. Eur. Ceram. Soc., 2002.

19. J. Martínez-Fernández, F.M. Varela-Feria, A. Domínguez Rodríguez, and M. Singh, "Microstructure and thermomechanical characterization of biomophic silicon carbide-based ceramics", in Environment Conscious Materials; Ecomaterials., ISBN: 1-894475-04. Canadian Institute of Mining, Metallurgy, and Petroleum, 2000, 733-740. 